\title{
Cultural Interaction at Hassek Höyük, Turkey. New Evidence from Pottery Analysis
}

\section{Barbara Helwing}

\section{Citer ce document / Cite this document :}

Helwing Barbara. Cultural Interaction at Hassek Höyük, Turkey. New Evidence from Pottery Analysis. In: Paléorient, 1999 , vol. 25, n¹. L'expansion urukéenne : perspectives septentrionales vues à partir de hacinebi, hassek höyük et gawra. pp. 91-99; doi : https://doi.org/10.3406/paleo.1999.991

https://www.persee.fr/doc/paleo_0153-9345_1999_num_25_1_991

Fichier pdf généré le 24/04/2018 


\begin{abstract}
Pottery analysis at Hassek Höyük revealed inconsistencies in the material record, where it is possible to identify a group of hybrid pottery combining stylistic and technological features of both the Uruk and the Syro-Anatolian Late Chalcolithic cultures. This hybrid pottery at Hassek Höyük is interpreted as the work of local craftsmen who, during a period of intensive contact with the Uruk culture, integrated some features of the Uruk pottery into their own production mode. The continuous use of chaff tempered clay shows a strong conservative tendency and argues for a local continuity of craftsmanship. Thus, the pottery production at Hassek is deeply rooted within the local cultural tradition of the Syro-Anatolian Late Chalcolithic. This is a strong argument against the interpretation of the site as being a wellplanned colony erected on virgin soil by a group of foreign Uruk traders.
\end{abstract}

\title{
Résumé
}

La céramique chalcolithique de Hassek Höyük a permis de démontrer l'existence d'un groupe hybride qui allie des éléments stylistiques et technologiques de la culture d'Uruk et du Chalcolithique récent de Syro-Anatolie. Cette céramique hybride est considérée comme le produit d'artisans autochtones qui, pendant une période de contact avec la culture Uruk, auraient intégré quelques caractères de la céramique Uruk dans leur mode de production. L'emploi d'argile dégraissée avec de la paille montre une tendance très conservatrice et indique une continuité artisanale. Ainsi, la production de céramique à Hassek Höyük a ses racines dans la tradition culturelle indigène du Chalcolithique récent de SyroAnatolie. C'est un argument fort contre l'interprétation du site comme celle d'une colonie planifiée, construite sur le sol vierge par un groupe étranger de marchands urukéens. 


\title{
CULTURAL INTERACTION AT HASSEK HÖYÜK, TURKEY. NEW EVIDENCE FROM POTTERY ANALYSIS
}

\author{
B. HELWING
}

\begin{abstract}
Pottery analysis at Hassek Höyiik revealed inconsistencies in the material record, where it is possible to identify a group of hybrid pottery combining stylistic and technological features of both the Uruk and the Syro-Anatolian Late Chalcolithic cultures. This hybrid pottery at Hassek Höyük is interpreted as the work of local craftsmen who, during a period of intensive contact with the Uruk culture, integrated some features of the Uruk pottery into their own production mode. The continuous use of chaff tempered clay shows a strong conservative tendency and argues for a local continuity of craftsmanship. Thus, the pottery production at Hassek is deeply rooted within the local cultural tradition of the Syro-Anatolian Late Chalcolithic. This is a strong argument against the interpretation of the site as being a well-planned colony erected on virgin soil by a group of foreign Uruk traders.

Résumé : La céramique chalcolithique de Hassek Höyük a permis de démontrer l'existence d'un groupe hybride qui allie des éléments stylistiques et technologiques de la culture d'Uruk et du Chalcolithique récent de Syro-Anatolie. Cette céramique hybride est considérée comme le produit d'artisans autochtones qui, pendant une période de contact avec la culture Uruk, auraient intégré quelques caractères de la céramique Uruk dans leur mode de production. L'emploi d'argile dégraissée avec de la paille montre une tendance très conservatrice et indique une continuité artisanale. Ainsi, la production de céramique à Hassek Höyük a ses racines dans la tradition culturelle indigène du Chalcolithique récent de Syro-Anatolie. C'est un argument fort contre l'interprétation du site comme celle d'une colonie planifiée, construite sur le sol vierge par un groupe étranger de marchands urukéens.
\end{abstract}

Key-words : Hassek Höyük, Late Chalcolithic, Pottery, Hybridisation.

Mots clefs : Hassek Höyük, Chalcolithique récent, Céramique, Hybridisation.

\section{INTRODUCTION}

During the fourth millennium BC the first "high civilization" of Babylonia ${ }^{1}$, called the Uruk culture after the type site of Uruk (modern Warka), expanded northward and established settlement sites in Northern Mesopotamia. This process is often described as "the world's earliest known colonial network" 2. Within this model, the site of Hassek Höyük in Southeastern Turkey is interpreted as one of the

1. MOORTGAT, 1945; NISSEN, $1988: 65$. most remote 'colonial outposts' of the Uruk culture in the north. On closer examination, however, some features suggest that the site may have an indigenous origin and character ${ }^{3}$. The local aspects of Hassek become even more obvious from the analysis of the ceramic assemblage at the site: pottery production shows clear characteristics of the indigenous SyroAnatolian Late Chalcolithic tradition. The interpretation of Hassek Höyük as a 'colonial outpost' should therefore be critically reassessed since a correct understanding of the site is crucial to proving or disproving the colonial model.

\footnotetext{
2. AlGAZE, $1993: 2-3$.
} 
Colonies are generally defined as representing a "population movement whereby the new remote foundations stay in a special - cultural and political - relationship with the motherland" 4 . They are usually imposed onto a preexisting indigenous cultural background with which they interact and on which they also depend. In contrast to the imperialistic colonies of the $16^{\text {th }}-19^{\text {th }}$ century European powers, the Northern Uruk settlements are described as being "non-imperialistic trade colonies" based on peaceful exchange, providing the emerging central power in Babylonia with the raw materials it required ${ }^{5}$.

Until recently, the northern expansion of the Uruk culture was thought to have taken place only at the very end of the Uruk period, corresponding to levels V-IV at Uruk-Eanna. During this period, the Uruk culture reached its apogee, as is demonstrated by the elaborate monumental buildings, the division of labour into specialised craft production, a complex administration and finally the invention of writing. This cultural peak is confirmed by the impressive size of the site, now covering an area of at least 200 ha in contrast to the already substantial 70 ha during the Middle Uruk period ${ }^{6}$. It seems quite natural to assume that this impressive cultural system had an increasing demand for raw materials, and required secure access to the supply of those goods. The need to secure safe traffic in prestige items and raw materials between the south and the north would have resulted in an expansionistic policy and the establishment of a trade network of "non-imperialistic trade colonies" along the main trading routes leading to Uruk ${ }^{7}$. Some scholars have therefore interpreted the Uruk expansion as a "world-system" based on asymmetrical core-periphery exchange between a dominating central power in Babylonia and an underdeveloped northern periphery, exploited by means of Uruk trade colonies ${ }^{8}$. A major assumption of the World System model is the unambiguous dominance of a central power. However, while the political structure of the Babylonian Uruk towns is not known, it is most probable that their individual spheres of influence did not exceed their immediate hinterland ${ }^{9}$. It seems to be most realistic to picture them as small independent city-states. It is a matter open to discussion whether such small policies

3. E.g. the city-wall, as pointed out by BEHM-BLANCKE, $1992: 85-90$, with a different interpretation.

4. Der kleine Pauly 3, 1969: 274-275.

5. Stein, BeRnBECK et al., 1996; Edens, 1997.

6. NISSEN, $1995: 476$.

7. EDENS, $1997: 52-55$.

8. E.g. Algaze, 1993. Compare Stein, 1998, and Rothman, 1993 for a critique of the use of the World System model.

9. SChMANDT-BESSERAT, 1993: 209; NisSEN, $1995: 476$. would have been able to send out, control and protect remote colonies over a long period of time.

The so-called Uruk trade colonies in North Syria have all produced the complete set of genuine Uruk material culture. When compared with the Old Assyrian karums in Anatolia, one of the archaeologically best known trading colony systems, this is just the opposite of what could be expected from a pure trade colony. Textual evidence indicates that in the karum, foreign traders lived alongside the indigenous population. Relations between the two groups were regulated by agreements between the Anatolian and the Assyrian rulers. The material culture of the site, however, reveals foreign presence and contacts only in the administrative sector, where texts and Syrian seals point at international relations ${ }^{10}$. Houses and pottery used by the traders are - as far as we know today - Anatolian ${ }^{11}$. This shows, that the non-permanent presence of foreign traders which could be expected for a mere trade colony would leave almost no archaeological traces. Trade colonies seem to be no appropriate model for the explanation of the North Uruk phenomenon.

Recent research in some of the Northern Uruk sites has shown that genuine Uruk sites in the North, for example Tell Sheikh Hassan, were already established during the first half of the fourth millennium ${ }^{12}$, that is the Middle Uruk period, and lasted for several hundred years. Thus, the northern Uruk sites can now be distinguished chronologically into two groups, the older one corresponding to the levels IX-VII at Uruk - Eanna, the younger to Uruk - Eanna VII-VI, that is the end of the Middle Uruk period ${ }^{13}$. Even the latest of the Northern Uruk sites, for example Habuba Kabira South or Hassek Höyük, confirm that the Northern Uruk settlements were already deserted before the cultural apogee of the late Uruk period ${ }^{14}$.

This leads us to two conclusions:

1. We cannot correlate the Northern Uruk sites with the Babylonian Late Uruk culture as represented at the type site. Since the information dealing with the Early and Middle Uruk

10. Regional seal styles and minor imports are reported both from Kültepe karum II and Ib. See N. ÖZGÜÇ, 1953 and PORADA, 1976-1980 for a summary of the seal styles.

11. See ÖzGüç T., esp. 1953 : 208; ÖzGüç T., 1964; 1986, passim; comp. LARSEN, 1987: 55

12. BOESE, $1995: 256$, fig. 15 does not indicate the precise dates.

13. The periodisation of the site of Uruk itself is subject to a longlasting and fairly polemic debate, based on the appearance and disappearance of certain mass produced pottery types. A reassessment of the Eanna sequence pottery (SüRENHAGEN, 1986a; 1993) has revealed good evidence for the chronological correlation of the Northern Uruk sites with Eanna VIII-VI. BOEHMER (1993: 110-111), NisSEN (1993: 476, footnote 19) and others argue against this correlation.

14. Strommenger, 1980a; Sürenhagen, 1993: 68. 
phases in the south are very scanty, it is dangerous to extrapolate a civilizational advantage to the south when comparing it to the Northern Uruk sites. Thus, the hypothesis of an asymmetrical centre - periphery exchange system, as implied in the world system model, is based on very weak grounds.

2. The so-called Uruk colonies (or Northern Uruk sites) kept their specific cultural distinctiveness, as is visible in every aspect of their material culture, over a time span of several hundred years, sharing the stylistic developments of the Babylonian Uruk sites without really absorbing any element of the neighbouring indigenous culture.

We therefore have to face the question whether we can really talk about remote new foundations branching off a developing central power in Babylonia imposed onto an indigenous Syro-Anatolian background, or whether we need to reconsider our definition of the Northern Uruk sites. In addition, H.-J. Nissen has recently questioned the existence of an indigenous culture in the north during the time of the Uruk expansion ${ }^{15}$. It seems rather that the Northern Uruk sites fill a contemporary settlement vacuum in the Euphrates valley. On the other hand, continuous survey and excavation in Northern Mesopotamia have already revealed a large number of Middle Uruk settlement sites forming a continuous belt of settlements linking the Northern Uruk sites with the southern Gazira, the Zagros foothills, the Hamrin and the "heartland of cities". We can therefore now suggest for Northern Mesopotamia an uninterrupted Uruk cultural area stretching from the Middle Euphrates crescent to Babylonia with a complex settlement hierarchy, as at Brak and Nineveh, equal to that in the south.

North of this Uruk belt, a similar homogeneous cultural area of the Syro-Anatolian Late Chalcolithic ( $\mathrm{LCH}$; divided into several regional varieties) is apparent, stretching from the Amuq in the West to Gawra in the East and extending north at least as far as the Upper Euphrates, with remote finds in Cappadocia and Caucasia. Its material culture is best characterised by chaff-tempered pottery, evolving out of the chaff-tempered, mass produced 'Coba tradition' of the LCH $1^{16}$, and by the use of stamp seals with a distinctive iconography ${ }^{17}$. The settlement pattern suggests a two or three tier settlement hierarchy and a high degree of economic autonomy ${ }^{18}$.

15. NISSEN, $1995: 478$.

16. Du PLAT, TAYLOR et al., 1950; see p. 95 for a definition and discussion of 'Coba bowls'.

17. Frangipane, 1993; Stein, Bernbeck et al., 1996.

18. LUPTON, 1996.

\section{IDENTITY AND MATERIAL CULTURE}

In order to understand the relationship between these two distinct cultural areas, the Northern Uruk and the Syro-Anatolian Late Chalcolithic, we should examine the material culture at those sites near their common boundary which should represent a contact and interaction zone of varying width. This can be done by examining their respective material culture from which their cultural identity is drawn.

Cultural identity as reflected in the material culture record has been one of the key concepts of archaeological interpretation since the days of Gustav Kossinna and V. Gordon Childe $^{19}$. Their normative view of culture as an identity concept has since been replaced by an instrumental definition of group identity. As Barth and others have pointed out, the affiliation with a we-group as opposed to the others has been used as a means to create identities and allies based on the self-identification of the people involved ${ }^{20}$. This affiliation system was open to manipulation and could be changed by simple acclamation. In this approach, culture was no more than an arbitrary set of symbols used to manipulate identity. Equally, artifacts were seen as socially "passive" in material culture studies of the 1960 's ${ }^{21}$. Variation within the record was understood as being related to tradition and function, with only the nonfunctional 'style' being open to manipulation as an identity marker.

This instrumental understanding of culture has in the last years been challenged by an approach recognizing the active role of culture in the creation of identity, based on Bourdieu's theory of social practice 22 . Since, the active role of material culture as an agent in the culture process has also been recognized in archaeological studies ${ }^{23}$. It has been pointed out by S. Jones that the "construction" of ethnicity is mainly based on the deliberate use and display of cultural differences in order to affirm a we - they - opposition ${ }^{24}$. Contact between two cultural groups would reinforce the formulation of that oppositional pair and encourage the use of culturespecific symbols in order to express the affiliation with - or the opposition to - one of the groups involved. Therefore, border areas would be well suited to trace the effects of culture contact, since in these areas, people would be forced

19. For a summary, see VEIT, 1989.

20. BARTH, 1969.

21. E.g. BINFORD, 1962; 1965.

22. BOURDIEU, 1976.

23. Emphasizing the function of style as a means to communicate group affiliation, e.g. CONKEY, 1990.

24. JONES S., 1996: 69. 
by the experience of 'the Other' to express their group affiliation more clearly.

Response strategies to such a foreign encounter are numerous ${ }^{25}$ and can vary from outright rejection to complete assimilation with a variety of stages in-between, reflecting either the spread or the acceptance of foreign cultural elements by the different groups involved ${ }^{26}$. In the interaction area, a zone of mixed and decontextualized cultural features can be expected, which reflect a process of continous 'hybridisation' in the contact area ${ }^{27}$.

Such a cultural blend should also be visible in the material record where the mixing of different technological and stylistic features would create new categories of objects - hybrid objects - which are not consistent with the original categories. They reflect a continous creative process wherein different objectives need to be considered ${ }^{28}$. In order to understand the mechanisms behind that hybridisation process, we can therefore analyse the pattern of material culture for discontinuities - blends or hybrids. Each of these discontinuities would mirror a deliberate decision of the producer which necessarily is based on his personal experience of the world, including his personal group affiliation.

Accepting the Northern Uruk as an integral part of the Uruk cultural area, we can now search for discontinuities and hybrids in the material record of the contact belt in order to understand the relationship between the Uruk sites and their neighbours further north. This can be done by briefly interpreting the results of the Hassek Höyük pottery analysis. Extrapolating from these results, a model describing possible culture contact between the Uruk sites and the Syro-Anatolian sites can then be proposed.

\section{HASSEK HÖYÜK - STATUS OF RESEARCH}

The site of Hassek Höyük is located on the left bank of the Euphrates River, $20 \mathrm{~km}$ below the castle of Gerger which marks the end of the river's course through the Taurus Mountains Chain. It lies on a natural hillside providing an

25. Comparc HODDER, 1979, about the variability of stylistic expressions of group affiliation.

26. HÖLSCHER, 1988

27. The term 'hybridisation' is widely used in culture contact studies to describe the mixing and blending of different cultural traits, comp. vaN DOMMELEN, 1997 : 309; HANNERZ, 1994; THOMAS, 1996: 126.

28. See KRAMER, 1997: 39-80, esp. 71, about the different reasons for variation in the pottery making process, reaching from tradition and function to aethestics and marketing strategies, whereby concepts like imitation and emulation are used. extensive view over the river bend and is very close to an ancient crossing of the Euphrates.

As part of the Lower Euphrates Salvage Project, Hassek Höyük was excavated between 1978-1986 by M.R. BehmBlancke on behalf of the German Archaeological Institute, Istanbul ${ }^{29}$. The excavations revealed a total of five cultural layers belonging to the late fourth and early third millennium BC. The lowermost layer 5 (late chalcolithic) is subdivided into three phases (a-c). The earliest occupation remains, Phase $5 \mathrm{c}$, are poorly preserved: they are found mainly in the northern part of the settlement and in the western sounding outside the later enclosure wall : they have been interpreted as temporary huts belonging to the first Uruk settlers at Hassek, in charge of the construction of the Phase 5a-b buildings on top of the hill. Based on pottery analysis results, it can now be shown that the Phase $5 \mathrm{c}$ settlement is much older than the Phase 5a-b settlement and belongs to the local Syro-Anatolian LCH as attested in Kurban and Karatut Mevkii and other sites in the area ${ }^{30}$. Most of this old settlement has been lost due to a later landslide.

Phases $5 \mathrm{a}$ and $5 \mathrm{~b}$ were partially contemporary and ended in a heavy conflagration ${ }^{31}$. The settlement of Phases $5 \mathrm{a} / 5 \mathrm{~b}$ consisted of a fortified acropolis with a set of buildings inside. Among them, the tripartite House 1 and the single room building House 3 reproduce a representative architectural unit as is known from Habuba Kabira South ${ }^{32}$. The Southern building, fragmentary walls which seemed to belong to a much larger building, is reconstructed by Behm-Blancke as a tripartite temple.

Glyptic evidence shows the participation of the Hassek population in a trade system connecting Mesopotamia and Eastern Anatolia in which their own trade contribution consisted of the mining and processing of the local high quality flint. The impression of a genuine Uruk community seemed to be confirmed by the limited range of the identifiable Uruk pottery types such as nose lugged jars, vessels with reserved slip surface decoration and bevelled rim bowls, all held to be infallible characteristics of an Uruk culture pottery inventory ${ }^{33}$. It is therefore quite understandable that Hassek Höyük has been treated as a genuine Uruk site and, within the colony model, as a remote outpost of the Uruk long distance trade system $^{34}$.

29. Behm-BLANCKe, $1981 ; 1984 ; 1992$.

30. HeLwiNG, forthcoming.

31. For a comprehensive site plan, comp. BEHM-BLANCKE, 1992 : pl. 31.

32. This comparison has already been pointed out by BEHM-BLANCKE, 1992: 84-86, fig. 73 .

33. НОН, $1981 ; 1984$

34. Behm-Blancke, 1992; Algaze, 1993 b. 
A closer look at the pottery assemblage from the site, however, challenges this interpretation. If one excludes the mass produced Uruk types (Bevelled rim bowls and Tall flowerpots) $)^{35}$, which together form more than one third of the ceramic assemblage, a closer examination of the remainder suggests that this interpretation of the Hassek Höyük pottery assemblage needs to be modified.

\section{FABRICS}

The remaining diagnostic in situ material at Hassek consists of ca. $45 \%$ mineral-tempered plain simple wares, a fabric usually considered to be Uruk in origin; $34 \%$ chafftempered pottery continuing the local Amuq $\mathrm{F}$ chaff-tempered tradition; and with $17 \%$ local cooking pot ware. The other groups consist of less than $1 \%$ black polished pottery and $3 \%$ undistinctive material. Compared with the standard Uruk ceramic inventory, as seen at the contemporaneous site of Habuba Kabira South ${ }^{36}$, the predominance of the local pottery fabric at Hassek is evident (fig. 1).

\section{SHAPES}

The pottery shapes at Hassek Höyük include a wide range of Uruk related forms, such as nose lugged jars, reserved slip ceramics, jars with bent spouts, and high-shouldered slim pithoi comparable to the Riemchengebäude material at Uruk (fig. 2). On the other hand, there is also a corpus of characteristic local pottery, best illustrated by the handmade burnished cooking pots ${ }^{37}$, and a small amount of Eastern Anatolian pottery, like the small black polished Karaz jar from House $3^{38}$. In addition, there is a third group consisting of pottery shapes developed from the older Amuq $F$ types: hammerhead-profile bowls and carinated bowls are amongst the most characteristic shapes of this group (fig. 3). The typological predecessors of this third group can be traced back to the Arslantepe VII corpus ${ }^{39}$, but the Hassek shapes are thin-walled, indicating the use of the fast potter's wheel.

35. Bevelled rim bowls occur in a number of sites alongside a merely local assemblage, e.g. at Tell Leilan, SCHWARTZ, 1988.

36. I want to thank Dietrich Sürenhagen for making the manuscript of the Habuba Kabira South final publication available to me.

37. E.g. $\mathrm{HOH}, 1984$ : fig. $13: 4,7,8,9$.

38. $\mathrm{HOH}, 1984$ : fig. $12: 5$.

39. FrangIPANE, $1993:$ fig. $9: 1-5 ;$ fig. $10: 3-5$.

\section{Fabrics: Hassek and Habuba in Comparison}

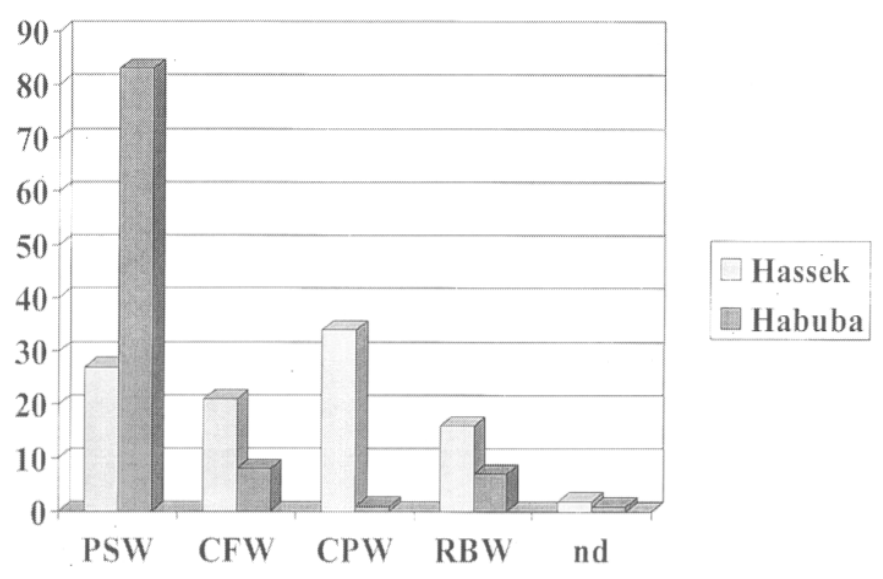

Fig. 1 : Comparison of Fabrics at Hassek Höyük and Habuba Kabira South (PSW : minerally tempered plain simple ware; $C F W$ : chaff faced ware; CPW: local cooking pot ware; $R B W$ : Syro-anatolian fineware and red black burnished ware; (nd: not determined).

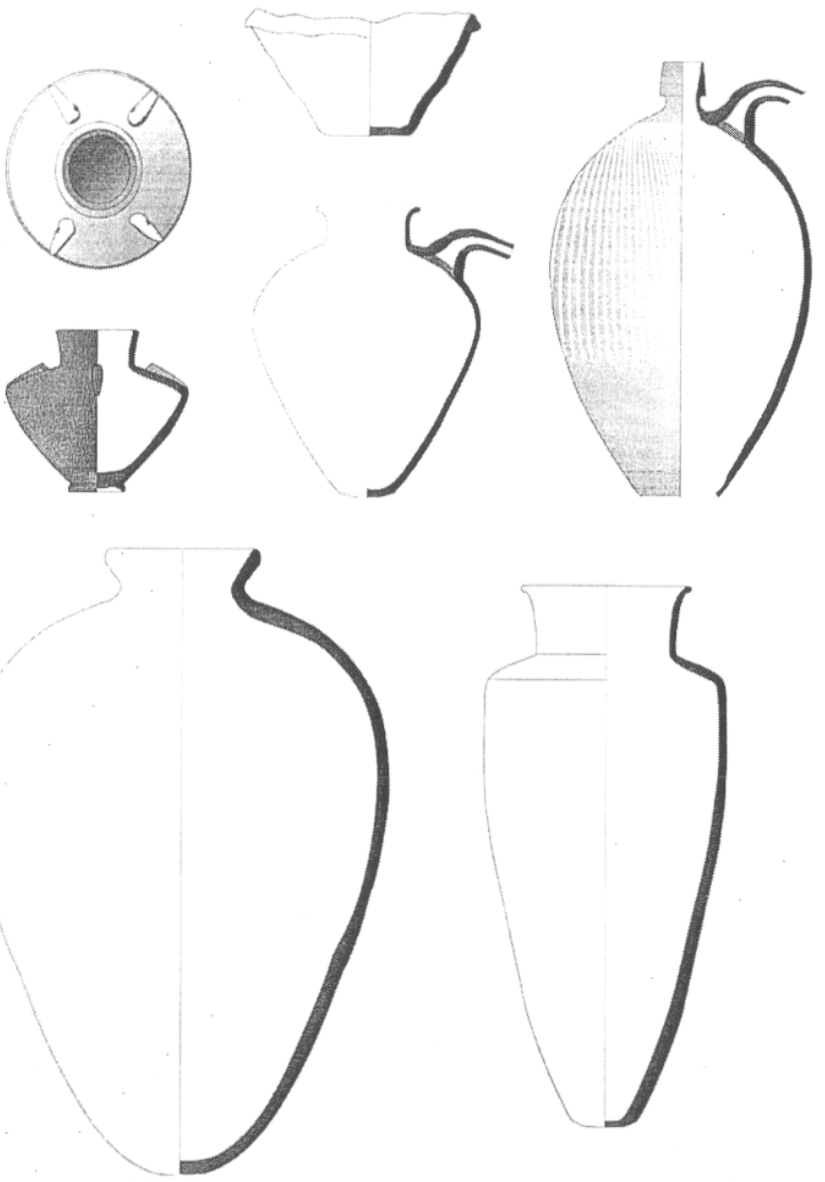

Fig. 2 : Hassek Höyük : Uruk Pottery. 


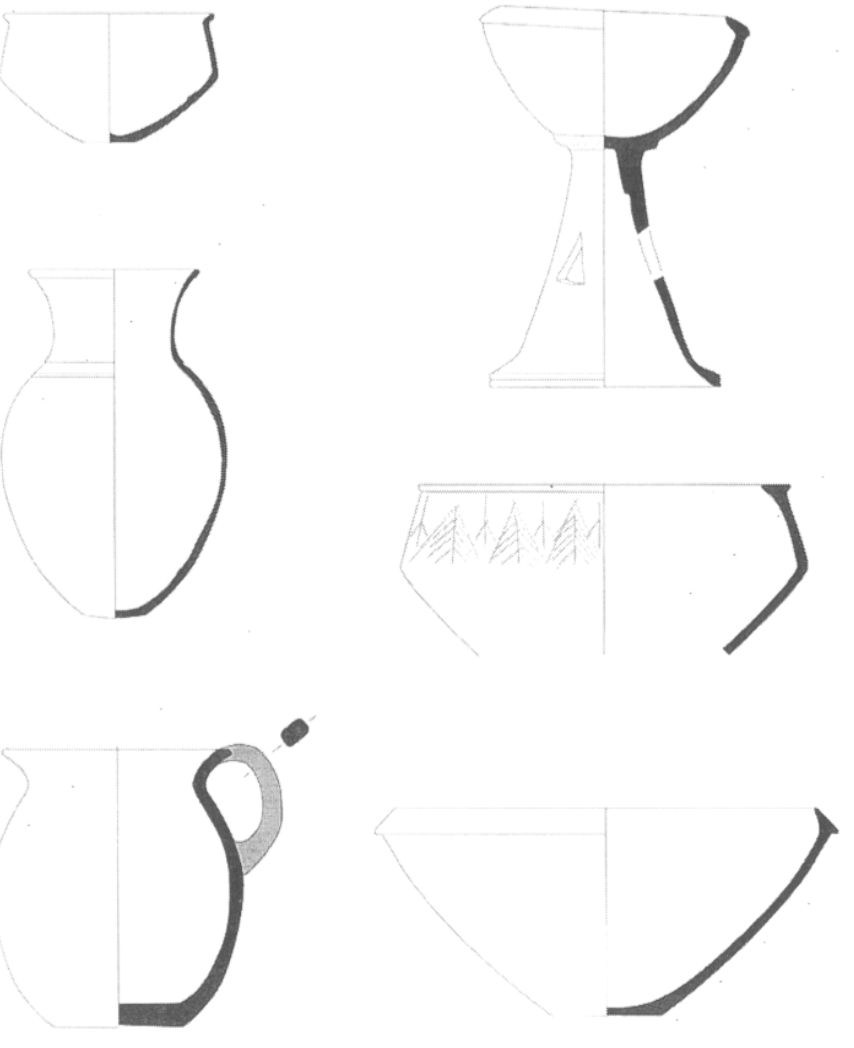

Fig. 3 : Hassek Höyük: Indigenous Syro-Anatolian Pottery.

\section{RELATION OF FORM AND FABRIC}

When the combination of shapes and fabrics are examined in detail, instead of the anticipated twofold inventory of local and Uruk types with a consistent correlation between ware

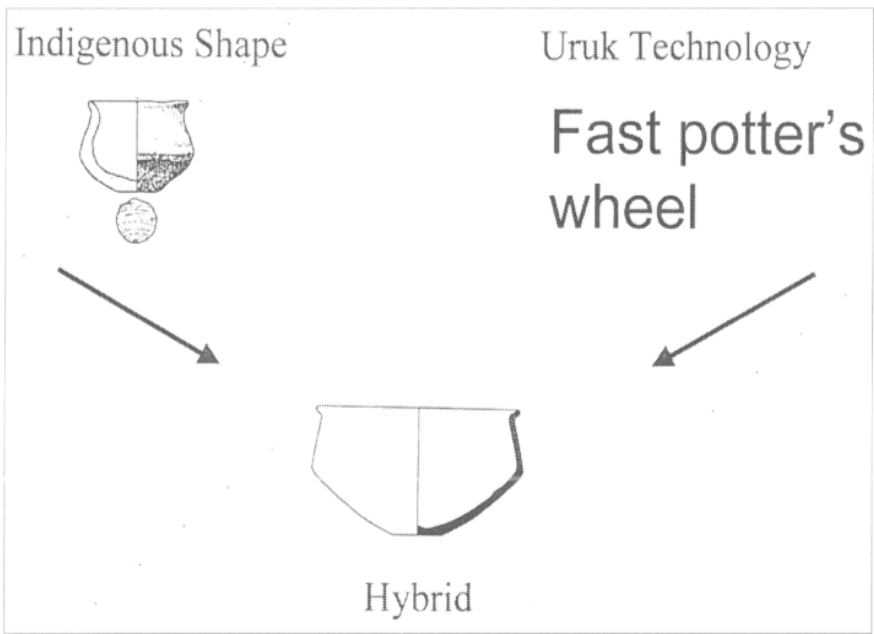

Fig. 4a: Hybridisation Case 1: Indigenous technology and Uruk shape. and form, we observe a different pattern. First, only a selection of the Uruk shapes has been produced in mineraltempered plain simple ware, while a larger amount of Uruk shapes has instead been produced from chaff-tempered fabrics. Second, when we examine the ceramic forms most typical of the local tradition, e.g. the carinated bowls and the hammerhead-profile bowls, only a fraction were produced in the characteristically local chaff-tempered fabric, while others were made from mineral-tempered plain simple ware pastes (generally considered to be characteristic of Uruk pottery). This mingling of different technological and stylistical traditions can be interpreted as being related to a constant exchange of these features from neighbouring traditions and is here called hybridisation.

Detailed analysis of the Hassek Höyük pottery assemblage in fact suggests that it can be divided into four production categories :

1. Classic Uruk pottery, showing the combination of Uruk shapes and fabrics (plain simple ware).

2. Local LCH pottery, handmade burnished cooking pots and some chaff tempered pottery.

3. Pottery related to the Upper Euphrates LCH material from sites like Tepecik and Arslantepe.

4. A group of hybrid pottery combining different craftsmen traditions, which can be further divided into:

4a. Uruk shapes produced in chaff-tempered fabrics; this is interpreted as reflection of the production of Uruk-like looking pottery or imitations aiming at the display of a cultural affiliation with Uruk culture but not achieved in perfection (fig. 4a).

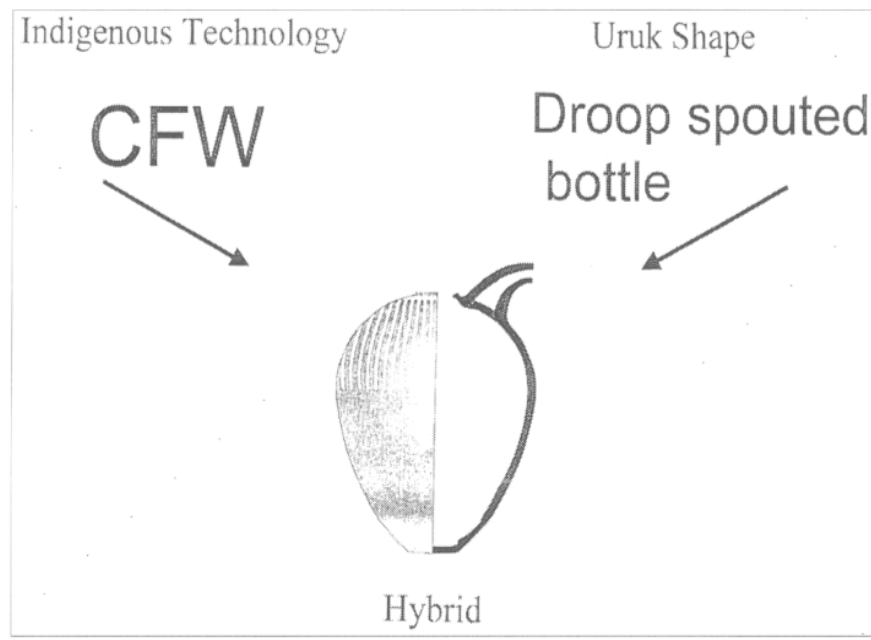

Fig. 4b: Hybridisation Case 2: Indigenous shape and Uruk technology (Indigenous shape from Arslantepe VII, after FRANGIPANE, 1993 : fig. 9: 3). 
4b. Local shapes produced on the fast wheel using minerally tempered clay; this reflects the borrowing of a foreign technology by the indigenous potters in order to improve their handicraft (fig. 4b).

If each of these production categories was linked to a discrete group of users, or served different functions, spatial analysis should reveal some coherent pattern. Based on this assumption, the distribution of the different pottery types and groups within the settlement was plotted with the following results :

1. All four production categories were equally distributed over the whole settlement area, although genuine Uruk pottery (category 1) was rare. Therefore no discrete spatial distribution between the different categories is visible.

2. A slight increase in chaff tempered pottery in the northern part of the settlement is probably due to residual sherds from the older Phase $5 \mathrm{c}$ settlement.

3. The two "typical" Uruk style buildings (the tripartite House 1 and the "reception house", House 3) were both used for household activities: both have fireplaces and storage areas, with vessels for storing grain, and neither shows signs of restricted use typical of a representative or public building.

4. The only place where a small concentration of real Uruk pottery (category 1) could be detected is the corridor separating House 1 and the Southern monumental building ${ }^{40}$ : the forms were restricted to storage vessels and it can be suggested that the corridor was a storage area for goods purchased from Uruk communities elsewhere.

The identification of the four production categories of pottery at Hassek Höyük allows to single out different workshops working in different technological traditions. The hybrid group, category 4 , would be consistent with the existence of independent local craftsmen who, during a period of intensive contact with the Uruk culture, integrated some features of the Uruk pottery tradition (like the use of the fast wheel) into their own production mode. These new improved methods naturally affected the shape and style of the locally produced pottery, as is reflected by the thin-walled hammerhead profile bowls and other forms whose typological predecessors can be traced back to the preceding local cultural stage at Arslantepe VII. However, the continued use of chaff tempered fabrics shows a strong conservative tendency and argues for a local continuity of craftsmanship. At the same time, the imitation of Uruk pottery forms in local fabrics reflects the deliberate assertion of an Uruk cultural affiliation without really being convincing. This may reflect the attempt

40. See Behm-Blancke, 1992 : pl. 31, room 5. to match the taste of local clients who would want to express their personal relation with a foreign culture.

Other classes of material culture found at Hassek Höyük equally show a strong link with local technological traditions. E.g., the bulk of lithic production is based on the socalled 'canaanean blade technology'. This particular technology used to obtain standardised long blades is introduced during the first half of the 4th millennium BC in Late Chalcolithic sites in Southeastern Anatolia and the Northern Levant and is only later found as far south as Egypt ${ }^{41}$, so that it can be considered to be a genuine Syro-Anatolian feature. Other aspects of material culture at Hassek Höyük are still under study ${ }^{42}$. However, it has already been pointed out that the curved enclosure wall surrounding the acropolis at Hassek can rather be compared to later examples from Tarsus and other Anatolian sites and shows no similarity with the rectangular fortification walls with regular bastions as they are known from Habuba Kabira South and Tell Sheikh Hassan ${ }^{43}$. Seals found at Hassek Höyük comprise different groups. Two Late Chalcolithic stamp seals found in secondary context ${ }^{44}$ could point at the existence of administrative structures probably already during the existence of the Hassek $5 \mathrm{c}$ settlement. Cylinder seals with simple geometric designs, like the eye motif, were found at Hassek Höyük ${ }^{45}$, but their interpretation as either genuine Uruk style or hybrid products remains difficult. Sealings with foreign designs might point at trade items being brought into the site from either the north ${ }^{46}$ or the south ${ }^{47}$.

Due to its chronological position at the very end of the Northern Uruk, the assemblage from Hassek Höyük 5a-b can best be interpreted as representing the final outcome of a longer acculturation process. Earlier stages of interaction in sites of the contact belt which can be traced (at, for example, Hacinebi ${ }^{48}$ point to a preceding phase during which a spatial distinction of the two groups here living together in one village can be demonstrated.

Is the hybridisation visible in the Hassek ceramic assemblage a normal pattern in the interaction zone? Sites contemporaneous with Hassek Höyük within the Atatürk Baraji area certainly show a similar pattern : At the regional center

41. For a discussion of 'canaanean blades', see OTTE und BEHM-BLANCKE, 1992: 170-173; SCHMIDT, 1996 : 53-64; RoSEN, 1997: 44-65.

42. BEHM-BLANCKE und GeRBER, in prep.

43. BEHM-BLANCKE, $1992: 85$.

44. Behm-Blancke, $1981:$ pl. $12: 3:$ Behm-Blancke, $1984:$ pl. $12: 1$.

45. BEHM-BLANCKE, 1992 : fig. $75: 1-2$.

46. Ibid. : fig. $75: 7$

47. Ibid: fig. $75: 3$.

48. See STEIN, this volume. 
of Samsat Höyük ${ }^{49}$, we can trace the gradual shift from a purely indigenous assemblage to an inventory containing reasonable quantities of Uruk pottery dating to an older Middle Uruk phase. But up to the latest Uruk level, the local component is visible in the appearance of hammerhead profile bowls, so we can reject the idea of a complete replacement of the indigenous material culture. At Kurban Höyük ${ }^{50}$, the typological development of the indigenous forms points evenly to an integration of Uruk technology in the local manufacture. Pure Uruk pottery shapes and hybrid forms are both present. Hacinebi, which is close to the Syrian Uruk sites shows a spatial distinction of two contemporary cultural groups in the Middle Uruk period.

North of the Taurus, at the regional centre of Arslantepe ${ }^{51}$, Phase VIa which is contemporary to the younger Uruk sites like Habuba Kabira South, has a strong local component. Besides the few real Uruk sherds by fabric, the restricted range of Uruk shapes here seems to be hybrids, using a chaff tempered fabric. In the Upper Euphrates area at Tepecik ${ }^{52}$, we can observe a spatial distinction between the Uruk related building complex of Tepecik West and the main mound. However, most of the fabrics used in the production of the Uruk shapes at Tepecik West are chaff-tempered, and thinwalled hammerhead profile bowls are equally present.

The Jazirah sites again show a different pattern. Soundings at the regional centre at Tell Brak apparently have evidence for the complete replacement of an indigenous assemblage by an Uruk assemblage during the Middle Uruk period ${ }^{53}$. However, other contemporaneous sites in the vicinity, as far as they are known through excavation or survey ${ }^{54}$, do not adopt the usual Uruk pottery assemblage. They retain the local chaff-tempered tradition, and until the end of the period neither hybrids nor replacements can be positively identified (with the exception of the widespread use of the bevelled rim bowl). However, in this region we cannot exclude the existence of smaller Uruk settlements which might have escaped detection.

Thus, on the available evidence, three different patterns of material culture are displayed in the three regions discussed. In the case of Hassek, material culture traditions show quite clearly that at least part of the population, and certainly the potters, derive from the indigenous cultural background.

49. ÖZGÜC N., 1992.

50. ALGAZE, 1990.

51. Frangipane et Palmieri, 1983; Frangipane, 1997.

52. EsIN, 1974; 1976; 1979; 1982a : 1982b.

53. OATES and OATES, $1991 ; 1993: 1994$.

54. LYONNET, 1997; WILKINSON and TUCKER, 1995; MEIJER, 1986.
Therefore, the demonstrable display of Uruk features in hybrids of the ceramic assemblage is certainly the outcome of a deliberate strategy of the potters. It could be interpreted not only as the emulation of prestigious foreign styles and could even indicate the deliberate affiliation of the Hassek potters with the Uruk culture. The indigenous origin of the Hassek potters, even though it is hidden behind the Uruk features, is demonstrated by the nature of its ceramic material.

Thus, the pottery production at Hassek is deeply rooted within the local cultural tradition of the Syro-Anatolian $\mathrm{LCH}$, even though the adaptation of Uruk features deliberately tries to camouflage this affiliation. This, together with the proof for the existence of the older Syro-Anatolian Phase $5 \mathrm{c}$ settlement, is a strong argument against the interpretation of the site as being a well-planned Uruk colony erected on virgin soil by a group of Uruk traders, who would then have organized long distance trade to Mesopotamia in order to provide the motherland with urgently needed raw materials.

\section{CONCLUSION}

The extension of the Uruk cultural area up to the Euphrates crescent dates to at least the first half of the fourth millennium and is attested by the long and undoubted Uruk cultural sequence at Tell Sheikh Hassan. It coexisted with an indigenous culture in the area adjacent to the north. This culturally distinct neighbourhood remains unaltered in terms of the individual material culture over a time span of several hundred years. Contacts between these two groups are attested but they remain culturally separate as can be seen from the spatial separation of Uruk-related and indigenous areas in Hacınebi. Most probably the durability of this coexistence is due to different subsistence strategies of the groups involved : one was based on rainfed agriculture and was additionally involved in a trade network extending as far as Palestine and the Upper Euphrates, dating back far beyond the beginnings of the Uruk contacts; the other was based partly on specialized occupations, such as the processing of trade materials (visible from the different workshops in Habuba Kabira South), and later yet equally involved in that same trade network : exchange between these two groups is restricted in the Uruk sites mainly to required trade items, as perhaps flint implements, metals, and an unknown material stored in the characteristic aryballoi. It may also extend to some additional every day items purchased from their Syro-Anatolian neighbours : $10 \%$ of the ceramics at Habuba Kabira South were 
locally made burnished cooking pots which most probably held local agricultural products. On the other hand, those Syro-Anatolian communities in contact with the Uruk sites had access to staple goods stored in characteristic Uruk vessels, for example nose lugged jars and Riemchengebäude jars. Those goods may have equally represented prestige items for the Syro-Anatolian communities. The possibility that the forms of these containers are subsequently slowly integrated into their own material culture by imitating the most characteristic elements needs to be considered. The borrowing of new technologies would have been integrated even faster into the traditional craftsmanship.

Given an assumed prestige value for the exotic materials exchanged, it can further be concluded that the degree of the status expression in local elites would have been increasingly linked to the display of exotic taste and style, as finally represented by the construction of a purely Uruk-style tripartite building complex at Hassek Höyük, apparently used as a simple kitchen area by the local clients.
The final collapse of the Syro-Anatolian/Uruk network, which was probably at least partly due to external factors, affected most of the sites along the Upper and Middle Euphrates no matter what their cultural affiliation was. It was only after that collapse that the late Uruk urban centers of Mesopotamia - like Uruk itself - began to flourish and expand to the extent which is usually considered normal for the Uruk period. This might be due to a reverse flow of information, population and manpower from Syro-Anatolia back to Mesopotamia, resulting from the collapse of the Northern Uruk sites and the subsequent need to find new solutions to the old problems of supply of the necessary raw materials within the immediate neighbourhood.

Barbara HELWING

Bilkent University Dept. of Archaeology and History of Art Faculty of Humanities and Letters 06533 Ankara - Turkey 